\title{
The Explicit and Implicit Meaning Potential can Change in the Process of the Translation from the Indonesian Text to the English Text in Tempo Magazines
}

\author{
Yulia Arfanti ${ }^{1}$, T. Silvana Sinar $^{2}$, Zubaidah Ibrahim Bell ${ }^{3}$, Syahron Lubis ${ }^{4}$ \\ 1,2,3,4 Department of Linguistics, Postgraduate School, University of Sumatera Utara- Indonesia
}

\begin{abstract}
This article studies the explicit and implicit meaning potential which can change in the process of translation from the Indonesian text to the English one in Tempo magazines. The study is focused on Tempo magazines of the Indonesian version and the English one in the period of 2011-2013. The data were gathered qualitatively by using library research. The objective of the study was to find out the explicit and implicit meaning potential of the SL changed through the translation. The result of the study showed that there were the implicit meaning potentials of the SL which changed to explicit meaning potential through translation. There were explicit meaning potentials which changed to implicit meaning potentials of TL through the process of translation even though this type of change is rarely found in the process of translation, and there were the shifts of cohesion in text meaning potentials which changed through the process of the translation viewed from the cultural point of view which influenced the use of language.
\end{abstract}

Keywords: Explicit, Implicit, Meaning Potential, Tempo Magazines

\subsection{Background}

\section{Introduction}

Shifts are all mandatory actions of the translator, the actions which are dictated by the structural discrepancies between the language systems involved in this process and the optional actions which are dictated by his personal and stylistic preferences to which he resorts consciously for the purpose of natural and communicative translation of the SL texts into another language. Shifts can be defined as problem solving strategies adopted consciously to minimize the inevitable loss of meaning when rendering a text from one language into another.

In a text, we can find words, phrases, and clauses which have to be united and stuck to one another. By the help of cohesive components, texts can have a unity in connecting words, phrases, and clauses. The result is that if a text has a good unity, people will easily express the content of the text so that they will also be easy to translate it.

Cohesion is the network of lexical, grammatical, and other relations which link various parts of a text. These relations or ties organize and, to some extent, create a text; for instance, by requiring the reader to interpret words and expressions by reference to other words and expressions in the surrounding sentences and paragraphs. Cohesion is a surface relation and it connects together the actual words and expressions that we can see or hear. Cohesion constitutes a characteristic in a text.

In other words, a linguistic unit, especially a text which consists of clauses, can be called a text if the linguistic unit has a cohesion which means that one clause is connected with or related to other clauses. Cohesion is formed by cohesive meaning among the clauses. This cohesive meaning is realized by cohesive devices - reference, ellipses, substitution, conjunction, and lexical cohesion. The cohesive meanings among the clauses form a unity which is called a text. The cohesiveness in a text will be closely related if more cohesive devices are used in a text. In other words, the more cohesive devices exist in a text, the more cohesive the text is. The solid text is characterized by the extensiveness and intensiveness of the variation of cohesive devices in the text (Saragih, 2001: 137-08).

On level of cohesion, Kulka divides shifts in cohesion into two: a) Shifts in level of explicitness; namely, the general levels of the target text's textual explicitness are higher or lower than that of the source text; b) Shifts in the text meaning(s); namely, the explicit and implicit meaning potential of the source text changes through translation (Kulka, 2010).

Every language has a set of cohesive devices and preferred meaning for creating cohesive harmony (Hasan, 1985) and bonding pattern (Hoey, 1991). As a result, shifts in cohesion inevitably occur in translation. On this occasion, shifts in cohesion presumably occur in the magazines which are going to be analyzed in this dissertation. Therefore, the researcher is attempting to analyze the shifts in cohesion which are found in the TEMPO magazines, both in the TEMPO of the Indonesian version and the TEMPO MAGAZINE 
of the English version. She deliberately selects TEMPO magazines in both versions as the object of the analysis, due to some reasons as follows:

TEMPO magazine was firstly published in March 1971; it is a magazine which has frequently been banned. This indicates that this magazine prioritizes independency. This magazine is widely read by urban readers. Most of them are from middle-class people. They generally come from white collars and graduate at least from high schools to post graduate. Realizing the rapid advancement of the magazine circulation, the management of the magazine then published TEMPO MAGAZINE, that is, the English version of the TEMPO magazine, on September 20, 2000. This English version magazine adopted 80 percent of TEMPO magazine of the Indonesian version and 20 percent was adopted from other countries (http://www.anneahira.com/majalahtempo.htm). It can be said that TEMPO MAGAZINE of the English version, especially its cover stories, is the translation from TEMPO magazine of the Indonesian version.

On this occasion, the researcher assumes that there are many shifts of cohesion in the translation of TEMPO MAGAZINE of the English version. These shifts can be seen clearly in the translation of the titles of the headlines of the articles found in both versions.

\subsection{Concept of Shifts}

\section{Reviews of Related Literature}

Shifts are all the mandatory actions of the translator (those dictated by the

structural discrepancies between the two language systems involved in this process) and the optional ones (those dictated by his personal and stylistic preferences) to which resorts consciously for the purpose of natural and communicative rendition of an SLT into another language.

Catford argues that there are two main types of translation shifts; namely, level shifts where the SL item at one linguistic level (for example, grammar) has a TL equivalence at a different level (for example, lexis), and category shifts which are divided into four types:

1. Structure-shifts, which involve a grammatical change between the structure of the ST and that of the TL);

2. Class-shifts, when an SL is translated with a TL item which belongs to a different grammatical class, for example, a verb may be translated with a noun;

3. translation unit-shifts which involve changes in rank;

4. Intra-system shifts which occur when SL and TL process system which approximately correspond formally as to their constitution, but when translation involves selection of a non-corresponding term in the TL system; for instance, when the SL singular becomes a TL plural.

According to Nida (1969:107), "in many instances, shifts of components involve only a shift from a literal etymological meaning to one which is functionally more relevant." Nida's example for this case is the translation of the word 'devil' whose etymological meaning is "Satan". If translated, say, into Arabic, the word would mean nothing unless an etymological shift is used; for example, the translator has to refer to its etymological origin, then transfer it into the TL. Another type of componential shift goes from generic to specific meaning or vice versa.

Nida (1969: 89) points out that "the area of cultural specification, however, is likely to provide the greatest difficulties for the translator. In translating a text which represents an area of cultural specification in the SL but not in the receptor language, the translator must frequently construct all sorts of descriptive equivalents so as to make intelligible something which is quite foreign to the receptor. Popovic (1970:80) states: "Thus shifts do not occur because the translator wished to 'change' a work, but because he strives to reproduce it as faithfully as possible and to grasp it in its totally." Popovic's statement reminds us of many factors which affect the translator's adoption of a particular style in rendering a particular text into another language.

\subsection{Concept of Cohesion}

A unit of experience in one sentence can be connected or tied with another

sentence as an experience unit by cohesion. This tie forms a unit which is called cohesion. Cohesion constitutes a characteristic of a text. In other words, a linguistic unit, especially a text consists of a number of sentences. It is called a text if it is cohesive with means that a sentence is tied with another sentence. The concept of cohesion is semantic one. It refers to relation of meaning that exist within the text, and that define it as a text. Cohesion occurs where the interpretation of some element in the discourse is dependent on that of another ( Halliday and Hasan 1975:4)

Cohesion is formed by cohesive meaning among the sentences. This cohesion is realized by four cohesive devices: refernce, ellipsis/substitution, conjunction, and lexical cohesion (which consists of reiteration: repetition, synonym, and superordinate and collocation). 


\subsection{Shifts of Cohesion in Translation}

Blum Kulka quotes Halliday and Hasan ( 1976) points out that cohesion does much more than provides continuity and thus creates the semantic unity of the text. The choice is involved in the types of cohesive markers used in particular text can effect the texture as being "loose" or "dense" as well as the style and meaning of that text. On level of cohesion, She divides shift in cohesion into two:

a. Shift in level explicitness, namely the general levels of the target text's textual explicitness is higher or lower, than that of the source text.

b. Shift in text meaning(s); namely the explicit and implicit meaning potential of the source text changes through translations.

Cohesion in this study means cohesive relationship of meaning component in a semantic domain of a concept. Larson (1998:429) points out that semantic domain does not refer to using the same form or referring to the same specific item and over (this would be concordance), but rather to the fact that the things being referred to are from the same domain, i.e., center around the same topic or have certain semantic components in common, for example, from specific to generic meaning component or vice versa, from explicit to implicit meaning or vice versa.

\subsection{Cohesion Shifts of Expression}

In translating concept of meaning, it is often found that there is no exact equivalent between the SL and the target language expression due to linguistic differences of two languages. There will be expressions which have some of the meaning components combined in them matching an expression which has the components with some additional ones. There will be overlap, but there is seldom a

complete match between languages. Further, Blum - Kulka defined that on the level of cohesion, shifts in types of cohesion markers used in translation seem to affect translation in one or both of the following directions:

In order to make implicit information in translating, the process of interpretation performed by the translator on the source text might lead to a TL text which is more redundant than the SL text.

As pointed out by Bell (1991: 165), cohesion ties much more than mutual connection of components of surface texts within a sequence of clauses or sentences and accordingly create the semantic unity of the text. Since there is no same word in two languages, the translator's choice on meaning components of meaning concept involved in the type of cohesive markers used in a particular text can affect the SL explicit and implicit meaning potential of the SL.

Larson (1998: 44) stated that explicit information is the information which is overtly stated by lexical items and grammatical forms. It is part of the surface structure form. The implicit information is that for which there is no form but the information is part of the total communication intended or assumed by the writer.

a. The Explicit Meaning Potential of the SL Changes to Implicit through Translation

Based on the amount of shared information between SL and TL, further he added that the implicit information may consist of referential, organizational, and situational meaning. English has specific grammatical markers which are cohesively obligatory.

Example: SL : Mereka bergabung dengan orang-orang lama.

TL: They join with old people.(literal meaning)

TL: They are hooking up with old players. (Tempo, July 26, 2011)

Here, the phrase old players connotatively indicate their old colleagues or friends who probably supported them to obtain their position. The word, players implicitly indicates bad connotation; it could mean the plot or conspiracy. The two-verb phrase hook up literally means to catch (fish) with a fishhook. Therefore, the word bergabung (join) is translated to are hooking up which most probably has an implicit meaning; that is, bad connotation, too.

b. The Implicit Meaning Potential of the SL Changes to Explicit through Translation

To discover the similar related meaning concept of a lexical item, Larson (1998: 87) stated that it can be done by grouping and contrast as in part-whole relations and contrastive pairs:

For example:

SL: Lawan-lawan politiknya berusaha menggali dosa-dosa sang ketua

TL: His political opponents attempt to dig the sins of the chairman (literal meaning)

TL:Political opponents are working to uncover the misdeed of their party chairman.(Tempo, July 262011 )

The word menggali literally means to dig, but here it is translated to uncover. It indicates that menggali has implicit meaning, for dosa-dosa (sins) cannot be dug. The words dosa-dosa also have an implicit meaning since these words implicitly tells us about the misdeed of the party leader. It is not the sins which have the religious connotation, but it is the political ones. Again, sang ketua literally means the chairman. Of course, the translator needs to translate or to make it explicit by translating it to the party chairman. 


\section{Research Design}

The main data were obtained from Tempo magazines, either from the Indonesian version as the source text or from the English version as the target text. The raw data were presented in columns and classified based on the types, according to the subject matter of the research which was related to the shifts of meaning in cohesion found in the source text and in the target text explicitly and implicitly.

The analysis dealt with words, phrases, clauses which were found in the source text and then classified and analyzed the two texts in order to find out and to determine whether there were the shifts in meaning from the source text to the target text. The classified shifts which were related to the problems of the research were then extended. The extension was shifts in text meaning(s); namely, the explicit and implicit meaning potential of the source changes through translation.

\section{Findings}

As what has been explained by Bell (1991: 164-5), cohesion has the function of binding the text together by creating consequences of meaning; cohesion consists of the mutual connection of components of source text within a sequence of clauses/sentences. Halliday in Lawrence Venuti (2000: 299) states that the overt cohesive relationship between parts of the texts is necessarily linked to a language's grammatical system. Thus, grammatical differences between languages will be expressed by the types of ties used to matk cohesion in source and target texts. Since there is no same word in two languages, the translator's choice on meaning component of meaning concept involved in the type of cohesive markers.

Larson (1998: 44) further states that explicit information is the information which is expressed overtly by lexical item and grammatical forms. Information which is expressed implicitly is, of course, covered in form, but its information can be traced from some parts in the entire information assumed by a translator.

\subsection{The Explicit Meaning Potential of the SL Changes to Implicit Meaning Potential through Translation} Example:

a. ST: '...di ruang tahanan' (August 30, 2011, p.13 data)

TT: in custody

Literal translation: in detention room

The phrase, 'di ruang tahanan' in the source text is literally translated as in the detention room, but it is translated in the target text to the phrase, in custody. Here, the translator omits some words ('ruang' or room) in the process of the translation. The word, custody implicitly means that someone who is sent to prison or detention room; therefore, the translator uses the word, custody as the representation of the word detention. Here, there is no difference in meaning between detention and custody. In this case, the shift of cohesion occurs in the level of text meaning potential, from explicit to implicit.

\subsection{The Implicit Meaning Potential of the SL Changes to Explicit Meaning Potential of the TL through Translation}

Larson (1998: 87) states that to obtain similar related concept of lexical items can be done by grouping and contrasting as in part or in the whole relation in contrastive pair.

Example:

b. ST: ..'menancap'

TT: attached to

Literal translation: embedded something

\section{Discussion}

From the displayed presentation, it was found that shifts of cohesion in the translation of TEMPO magazines from the Indonesia version to the English version which is called the source text and the target text basically had the influence on the levels of shift in text meaning i.e., explicit and implicit meaning potential of the source text change through translations.

In the level of text meaning potential, the shifts mostly occurred in the level of explicit and implicit meaning potential of the source text changed through the translation. The shifts of cohesion in the level of text meaning potential were the shifts in the level of explicit and implicit meaning. In the level of meaning potential itself the shifts mostly included explicit meaning. On the other hand, the dominant shifts were from the implicit meaning in the source text to the explicit meaning in the target text. In the level of implicitness the shifts also occurred but not very significant because there was the difference in structure between the texts in the source language and the texts in the target language. These differences highly influenced the result of the translation of the languages. 


\subsection{Shift of Cohesion Influences the Meaning of the Translation from the Indonesian Text to the English} Text

The shift of cohesion which occurred in the level of explicitness was in the general level of the target texts' textual explicitness higher that of the source text. In this level, the shifts varied; they occurred in words, phrase, and clauses because there were unclear meanings in the source texts when they were 'transferred' to the target texts. Therefore, the translator used the procedure of the development in the translation process by adding longer phrases in the target texts so that the reader of the target text did not find any misunderstanding what it was intended by the context of the source text although it is not uncommon that the shifts did not have identical intended meaning with the source text; but, in general, the words, phrases, and the clause which were translated had represent the real meaning in the source text.

This can be seen in the following text: '...rapat tim kecil pada...'. The word, 'tim' (team) in the source text arises different meaning when it is translated literally as it is found in the source text: 'tim kecil' is literally translated to small team. Here, the translator should use his skill in finding the right translation for the words, phrase, or clauses in the source in such a way so that what has been intended in the source text can be 'transferred' to the target text by using general shifts and expanding the words to a team of representatives. The same is true for the clause: 'Menyamakan isi kepala Sembilan orang' is translated by adding some words: to get nine people to think along the same lines.

This condition also occurred in the level of explicitness lower than that of the source, that is, the shift was in the general sense but it did not need to add some words as what happened in the level of explicitness higher than that of the source text. On the contrary, the word(s) were reduced or even eliminated the words in the source text in order to avoid the wrong interpretation of the reader in the target text.

The following is the example of the level of explicitness lower than that of the source text: 'wilayah temuan' in the source text is translated to findings in the target text. Here, the translator feels that he does not need to add some words in the target text; on the other hand, he even reduces the words so that there is no misinterpretation in understanding the meaning. The shifts of this kind are seldom found in the process of the translation in the diagram; they are only $12 \%$ of all shifts of cohesion.

\subsection{Shift of Cohesion in Text Meaning Potential Changes through the Translation.}

The shift of cohesion which is occurred in the explicit and implicit meaning potential of the source text changes through the translation because of the difference in the language system between the source language and the target language. As what Halliday and Hasan (1976) point out that cohesive ties do much moiré than provide continuity and thus create the semantic unity of the text. Kulka and Veniti (2000-3) point out that the first time a translator reads a text in which there is information which contains ambiguous meaning, he should trace further information so that he can develop a semantic meaning about the information, and it can be continued clearly to another reader in the target language.

Concerning the meaning brought in by a piece of information, Larson (1998:44) who points out that explicit information is a piece of information which is conveyed openly by the existence of lexical items and the existence of grammatical forms. In other words, explicit information is a part of the surface structure which has its form, while implicit information does not have form, but it is a part of the whole communication intended or assumed by the writer.

From the above explanation, it is found that the shift of cohesion in the level of text meaning potential can change according the meaning which comes from the ambiguous meaning in the source language; it is then transferred to the target language which makes the meaning clearer. In this case, it is categorized as the implicit meaning potential of the source language changes to the explicit one through the translation, as it has been quoted in the Findings as 'minta jata' (Findings: 395). In the source text, the word, 'jatah' has ambiguous meaning because it can have various meanings if it is translated to the target language. It will, of course, bring about misinterpretation; therefore, the translator should find the way how to find the appropriate word which is in line with what has been intended by the source language by tracing the previous paragraphs or the paragraphs after it in order to find the word in the translation which is not ambiguous. The translator, then, changes the literal word in translating the word, 'jatah' (allotment) to the appropriate one, money. Then the right translation for the phrase, 'minta jatah' is asked money in the target language.

On the other hand, shift of cohesion in the level of explicit meaning potential of the source text to the implicit one through the translation rarely occurs. This is proved in the findings which have been analyzed above. Most of the shifts of cohesion in the text meaning potential is dominated by the shifts of cohesion in the category of the implicit meaning potential of the source language which changes to the explicit one (since the reader of the target language needs transparent meaning so that he understands what he is reading about). Nevertheless, the shifts from the explicit meaning to the implicit meaning still exist (although they are very few). Here is two examples of the shift from the explicit meaning in the source language which changes to the 
implicit meaning in the target language. The phrase, 'terus menerus mengirim sinyal berbeda' in the source language should have been translated to continuously sent different signal. This is, of course, the explicit translation, but it is not what is intended by the context of the source language. The translator then translates it to a single word in the target language, [to] oppose which has the implicit meaning. Here, he uses two strategies to get good result in the translation: first, he reduces the number of words or changes the structure from the clause in the source language to the phrase or word in the target language or from the phrase in the source language to the word in the target language. Another example is the phrase, 'di ruang tahanan' in the source language which has the literal of the explicit meaning, in the detention room, is translated to the implicit meaning, in custody which means someone is arrested by the police (but not always in detention room; it can be house arrest or under city arrest). Custody can also mean someone who is taken care under someone else (The mother was given custody of the children).

\section{Conclusion}

After analyzing the shifts of cohesion which occur in the process of translation from the Indonesia version of TEMPO magazines to its English version, the researcher finally comes to the conclusion in this final chapter as follows

1. There are the Explicit Meaning Potential of the Source Language Changes to Implicit Meaning Potential through Translation.

2. There are the Implicit Meaning Potential of the Source Language Changes to Explicit Meaning Potential of the TL through Translation even though this type of change is rarely found in the process of translation.

3. Shift of Cohesion in the translation above had Influences on the Meaning of the Translation from Indonesian Text to the English Text

4. Shift of Cohesion in Text Meaning Potential Changes through the Translation viewed from the culture which influences the use of language.

\section{Acknowledgements}

This is part of doctoral dissertation and received sime comments from my promotors and copromotors. I am personally glad to thank Ali Pawiro for his careful proofreading, as well as his editing, of this articles earliest draft.

\section{References}

[1]. Al-Zaoubi, Muhammad Q.R. and Ali Rasheed Al-Hasnawi, 2001. "Continuing a Model For Shift Analysis in Translation" in Translation Journal and the Authors, Volume 5, No. 4, October 2001.

[2]. Baker, Mona. 1992. In Other Words: A Coursebook on Translation, London: Routledge

[3]. Bassnett, Susan. 1991. Translation Studies, Revised Edition, London and New York: Routledge.

[4]. Bell, Roger, T. 1991. Translation and Translating, Theory and Practice, London and New York:Longman.

[5]. Catford, J.C. 1965. A Linguistic Theory of Translation, London: Oxford University Press.

[6]. Emzir, Prof. DR. 2010. Metodologi Penelitian Kualitatif: Analisis Data, Jakarta: Raja Grafindo.

[7]. Halliday, M.A.K. and J.R. Martin (ed.). 1993. Writing Science, Literacy and Discoursive Power, London: Falmer Press.

[8]. Halliday, M.A.K. 1985. An Introduction to Functional Grammar. London: Edward Arnold.

[9]. Hatch, Evelyn and Hossein Farhady.1981. Research Design and Statistics for Applied Linguistics,Cambridge: Newbury House Publishers.

[10]. Hatim, Basil and Ian Mason. 1990. Discourse and the Translator, London: Longman.

[11]. Hung, Eva. 2002. Teaching Translation and Interpreting, Amsterdam: John Benjamin.

[12]. Kussmaul, Paul. 1995. Training the Translator, Amsterdam: John Benjamin.

[13]. Landers, Clifford E. 2001. Literary Translation, A Practical Guide, Clevedon: Multilingual MatterLtd.

[14]. Lorscher,Wolfgang.1991. Translation Performance,Translation Process and TranslationStrategies A Psycholinguistic Investigation, Germany: Gunter Narr Verlag Tubingen.

[15]. Munday,Jeremy. 2001. Introducing Translation Studies : Theories and Applications, London: Routledge.

[16]. Nababan, Mangantar. 2004. Translation Process, Practice, and Products of Professional Indonesian Translator, Unpublished Thesis, Wellington: Victoria University of Wellington.

[17]. Nida, A. Eugene. 1991. Language,Culture, And Translating, Shanghai: Shanghai Foreign Language Education Press.

[18]. Nida, A. Eugene. 2001. Contexts in Translating, Amsterdam: John Benjamin.

[19]. Nida,A.Eugine and Charles,Taber. 1982. The Theory and Practice of Translation, Leiden: EJ.Brill

[20]. Neste,Van.Ray.2004.Cohesion and Structure in the Pastoral Epistles,London:T\&T ClarkInternational

[21]. Newmark, Peter. 1988. A Text Book of Translation, London: Prentice Hall.

[22]. Pym, Anthony. 2010. Exploring Translation Theories, New York: Routledge.

[23]. Reah,Danuta. 2002. The Language of Newspapers, New York: Routledge.

[24]. Ricoeur,Paul.2006. On Translation, London: Routledge.

[25]. Sinar, Silvana T. 2003. Teori dan Analisis Wacana, Pendekatan Sistemik -Fungsional, Medan:Pustaka Bangsa Press.

[26]. Sinar, Silavana, T. 2008. Linguistics from Wikipedia, The Free Encyclopedia, Medan: USU Press.

[27]. Snell-Hornby. 1988. Translation Studies: An Integrated Approach, Amsterdam: John Benjamin.

[28]. Torop, Peter. 2002. Translation as Translating as Culture. Sign Systems Studies 30 : 593-605.

[29]. Toury, Gideon. 2004. The Nature and Role of Norms in Literary Translation, London: Routledge.

[30]. Venuti, Lawrence. 2000. The Translation Studies Reader, London: Routledge.

[31]. Venuti, Lawrence. 2004. The Translator's Invisibility, London: Routledge. 